\title{
Pathological effect of infectious bronchitis disease virus on broiler chicken trachea and kidney tissues
}

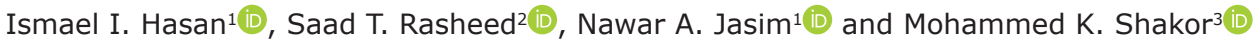 \\ 1. Department of Pathology and Poultry Diseases, College of Veterinary Medicine, University of Tikrit, Tikrit, Iraq; \\ 2. Department of Public Health, College of Veterinary Medicine, University of Tikrit, Tikrit, Iraq; 3. Salah-Adin Educational \\ Veterinary Hospital, Tikrit, Iraq. \\ Corresponding author: Ismael I. Hasan, e-mail: ismailhasan@tu.edu.iq \\ Co-authors: STR: drsaadrasheed@tu.edu.iq, NAJ: pdvet10@tu.edu.iq, MKS: dr.mohamad_khorshed@yahoo.com \\ Received: 15-05-2020, Accepted: 08-09-2020, Published online: 21-10-2020 \\ doi: www.doi.org/10.14202/vetworld.2020.2203-2208 How to cite this article: Hasan II, Rasheed ST, Jassim NA, \\ Shakor MK (2020) Pathological effect of infectious bronchitis disease virus on broiler chicken trachea and kidney tissues, \\ Veterinary World, 13(10): 2203-2208.
}

\begin{abstract}
Aim: This study aimed to investigate the pathological effects of the infectious bronchitis virus (IBV) on chicken trachea and kidney tissues and also desired to diagnose the virus genome using a molecular tool.

Materials and Methods: Twenty trachea and kidney samples collected from one broiler farm contain 10,000 chickens at Tikrit city. The chickens showed signs of gasping and mortality (20\%) at early ages (20 days old), the presence of IBV investigated using conventional reverse transcriptase-polymerase chain reaction technique with routine histopathological study to tracheal and renal tissue.

Results: Postmortem lesion showed severe respiratory inflammation with abscesses at tracheal bifurcation lead to airway blog. Molecular results showed two genotypes of IBV, one of them not included in primer designer research. The histological study showed different stages of inflammation, degeneration, and necrosis to the renal and tracheal tissues.

Conclusion: The respiratory and renal pathological effect of the virus responsible for the symptoms appeared on the affected chicks that caused mortality, with a high probability of presence of a new viral genotype added to the untranslated region.
\end{abstract}

Keywords: infections bronchitis virus, kidney, serotypes, trachea.

\section{Introduction}

Infectious bronchitis disease one of the viral diseases that affect poultry worldwide, causing economic losses, especially in small ages leading to growth retardation, loss of appetite, and mortality [1]. Chicken and other avian species are considered the natural host of the virus [2]. Infectious bronchitis is an air-born disease transmitted through direct and indirect routes [3]. Infections bronchitis virus (IBV) belongs to the Coronaviridae family is a single positive-sense RNA consist of about $27 \mathrm{~Kb}$ encoding to four structural proteins named nucleocapsid $(\mathrm{N})$, membrane $(\mathrm{M})$, envelope $(\mathrm{E})$, and spike (S) proteins [4]. The disease has many pathological effects on vital organs that lead to low egg production and quality; the virus also causing renal damage and is considered a predisposing factor for respiratory bacterial infection specially airsacculitis [5]. Vaccination failure against IBV frequently occurs due to the genetic material evolution of the virus [6]. Many serotypes were identified including

Copyright: Hasan, et al. Open Access. This article is distributed under the terms of the Creative Commons Attribution 4.0 International License (http://creativecommons.org/licenses/by/4.0/), which permits unrestricted use, distribution, and reproduction in any medium, provided you give appropriate credit to the original author(s) and the source, provide a link to the Creative Commons license, and indicate if changes were made. The Creative Commons Public Domain Dedication waiver (http://creativecommons.org/ publicdomain/zero/1.0/) applies to the data made available in this article, unless otherwise stated.
Massachusetts (Mass)-type [7] and QX genotype strains [8]. Genotypes and variants added a huge data impact on the genetic diversity of IBV [9]. Lack of cross-protection between IBV genotypes and emerging of new genotypes was always a problem in controlling and preventing the disease $[5,10,11]$. Several methods used for diagnosis of IBV, including the reverse transcriptase-polymerase chain reaction (RT-PCR) which consider a useful tool in comparing with serological methods [12].

Untranslated regions (UTR), which have high identification characteristics in reverse of the $\mathrm{S} 1$ region of the IBV genome, are used for rapid detection and classification for several IBV strain by generating PCR products ranged from $200 \mathrm{bp}$ to $433 \mathrm{bp}$ [13]. The hypervariable region of UTR that includes conserved flanking regions is the main characteristic feature of this region used as a diagnostic tool among different IBV strains [14]. Although this region used in differentiation between two strains, it is also used to show the similarity between other avian species viruses depending on UTR. Leghari et al. [15] showed that turkey coronavirus has a resemblance more than $78 \%$ when it compared with IBV. UTR also harbor the structural elements involved in replication and translation [16].

This study aimed to diagnose of IBV in suspected farm animals and to prevail the pathological effect of the virus on tracheal and renal tissue. 


\section{Materials and Methods}

\section{Ethical approval}

This study does not require ethical approval. However, all applicable international, national, and institutional guidelines for the care and use of animals were followed during the sample collection.

\section{Samples collection and histological preparation}

In January 2019 tissuesamples were collected from the suspected farm during IBV outbreak at Tikrit city. Kidneys collected from 20 suspected animals transported in the icebox to Laboratories of Tikrit University, piece of each sample stores at $-85^{\circ} \mathrm{C}$ for molecular investigation, while the whole samples kept in $10 \%$ formalin $24 \mathrm{~h}$ before it was placed in $70 \%$ ethanol and sent to laboratories for routine histological preparation [17]. The samples that showed positive IBV in the PCR test were sent for further pathological study while negative samples were neglected.

\section{Viral RNA extraction}

Total RNA extracted from animal tissue using QIAzol $^{\circledR}$ (Germany) reagent, $100 \mathrm{mg}$ of tissues cut into pieces with surgical blades and homogenized using of liquid nitrogen, procedure preceded, according to the manufacture instructions. RNA dissolved in $50 \mu \mathrm{L}$ DEPIC treated water and stored at $85^{\circ} \mathrm{C}$ until the time of use.

\section{Preparation of cDNA}

TonkBio ${ }^{\text {TM }}$ First-strand cDNA synthesis Kit (USA) used to prepare cDNA, $5 \mu \mathrm{g}$ of total RNA added to $1 \mu \mathrm{L}$ of $20 \mathrm{pmol}$ of OligodT primer, and $1 \mu \mathrm{L}$ of $20 \mathrm{pmol}$ of random primer and the volume completed up to $12.5 \mu \mathrm{L}$ with RNase free water, after incubation at $65^{\circ} \mathrm{C}$ for $5 \mathrm{~min}$ the mixture chilled in ice, spine down and the vial placed back on ice. 4 $\mu \mathrm{L}$ of $5 \times$ reaction buffer, $0.5 \mu \mathrm{L}$ of RNase inhibitor, $2 \mu \mathrm{L}$ of dNTP mix, and $1 \mu \mathrm{L}$ TonkBioTM M-MLV (200 U/ $\mu \mathrm{L})$ added. The components mixed gently and spinned briefly then incubated at $25^{\circ} \mathrm{C}$ for $5 \mathrm{~min}$, followed by $42^{\circ} \mathrm{C}$ for $1 \mathrm{~h}$. The reaction was terminated by heating at $70^{\circ} \mathrm{C}$ for 5 min and samples kept at $-85^{\circ} \mathrm{C}$ until time of use.

\section{Detection of Virus by UTR region amplification

Pair of primers All 1-F

5 '-CAGCGCCAAAACAACAGCG-3', Del1-R

5 '-CATTTCCCTGGCGATAGAC-3' used to detected IBV in suspected samples of chicken renal tissue using conventional RT-PCR amplifying segments ranges 200-433 pb. This primer identifies IBV strains targeting the most hypervariable region with conserved flanking regions in the IBV genome [13]. 10 pmol of each primer added to the cDNA $(100 \mathrm{ng} / \mu \mathrm{L})$ in the premix (Bioneer $\AA-k o r e a)$ tubes and final volume completed up to $20 \mu \mathrm{L}$ with distilled water. PCR carried out with thermocycler in which DNA denatured for $2 \mathrm{~min}$ at $94^{\circ} \mathrm{C}$, flowed by 35 cycles of denaturation $45 \mathrm{~s}$ at $94^{\circ} \mathrm{C}$, annealing $45 \mathrm{~s} 55$, extension $45 \mathrm{~s}$ at 72 , and a final single cycle of extension for $5 \mathrm{~min}$ at $72^{\circ} \mathrm{C}$. DNA electrophoresis was subjected using $2 \%$ agarose gel, which was photographed using of Geldocumentation system.

\section{Results}

Chickens of the affected farms showed signs of sneezing and lacrimation with a morbidity rate of $85 \%$ and a mortality rate of $20 \%$ at 20 -day olds ages. Postmortem lesions appeared as tracheal abscesses at the bifurcation site (Figure-1). This study was performed to investigate any potential changes caused by the virus in the trachea and kidney and to investigate the presence of IBV by depending on the UTR site that amplified by specific primer designed to differentiate among IBV strains.

Molecular results of renal tissue were subjected to a two-step RT-PCR test showed positive confirmation of IBV. The successful amplification of two fragments with a PCR product size of $433 \mathrm{bp}$ and $500 \mathrm{bp}$ (Figure-2) provides evidence for the presence of a virus genome but not determine the time of infection.

Histopathological study of renal tissue (Figure-3) showed signs of inflammation and

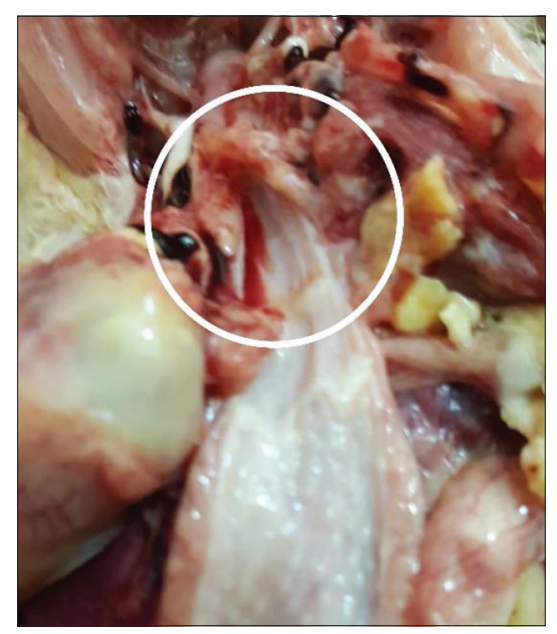

Figure-1: Recent mortal chick showed blockage of tracheal bifurcation by abscess leaked from one sectioned branch.

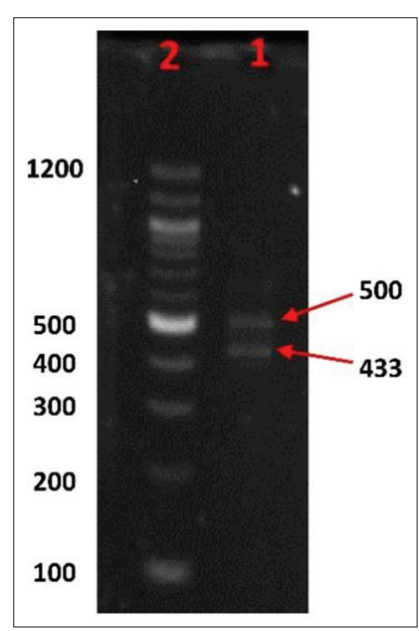

Figure-2: Agarose gel electrophoresis of PCR product; Len 1 Two IBV strain PCR product 500 bp and 433 bp, Len 2, Molecular weight marker 100-bp Ladder. 


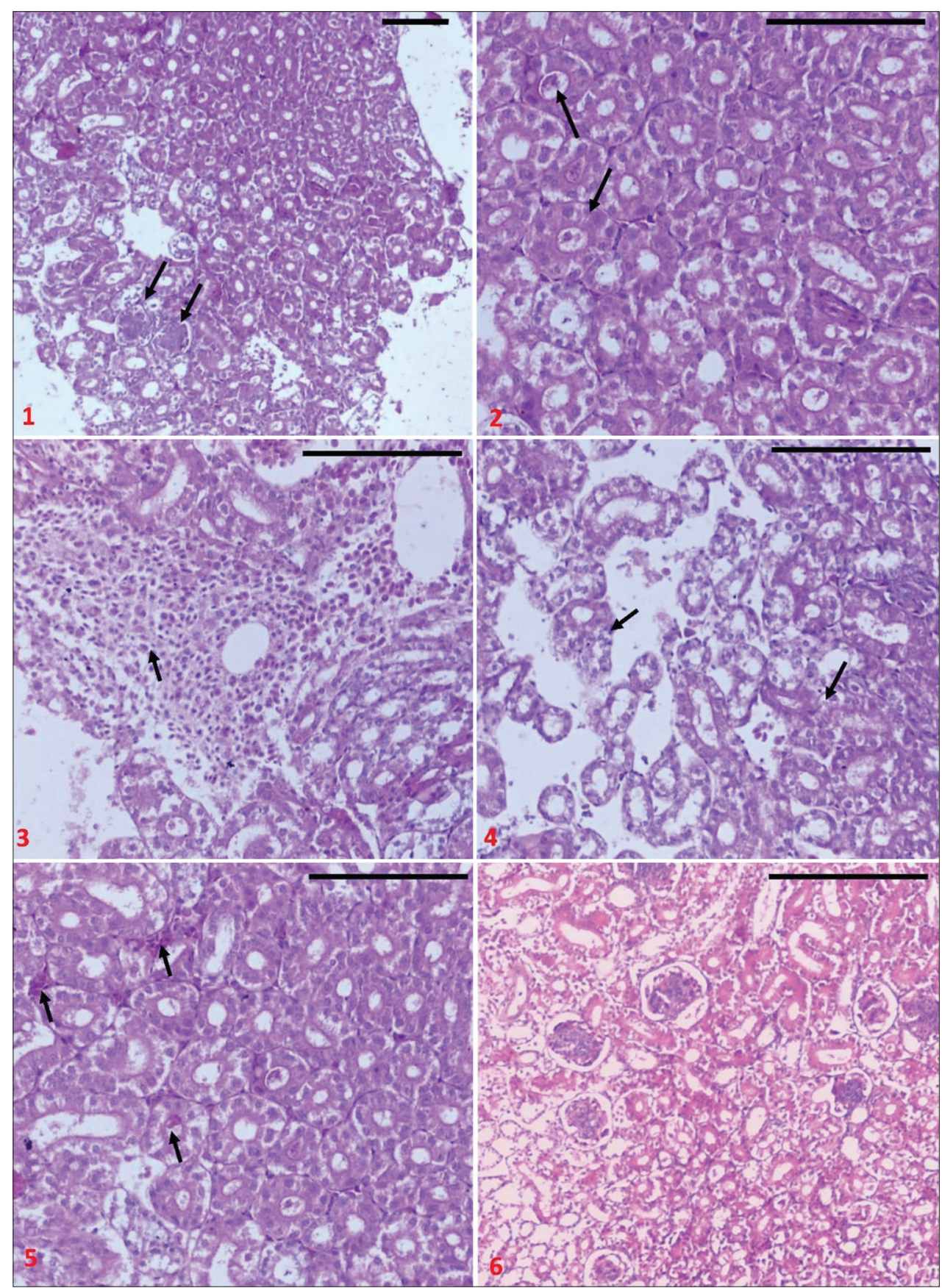

Figure-3: Kidney of broiler chicken infected with IBV, 1: Degenerated glomeruli 2: swelling of tubular epithelial cells with narrowing lumen, 3: Infiltration of inflammatory cells, 4: Necrosis, sloughing and fibrosis of renal tubules endothelia, 5: Renal interstitial congestion, 6: Normal tissue (Hematoxylin and Eosin staining; bar=100 $\mu \mathrm{m}$ ).

cellular degeneration. The signs included infiltration of neutrophils, disruption of glomeruli, different stages of corruption to the renal tubules. The renal tubules conducted a cellular swelling and narrowing of the lumen with cellular necrosis. In some locations, tubular endothelial cells were replaced by fibrin.

Pathological study to the tissue of the trachea (Figure-4) reveled a remarkable effect of IBV on the mucosal and submucosal area of the trachea. These changes included loss of epithelial cells with its cilia, sever hyperplasia leads to thinking in large epithelial areas, infiltration of neutrophils, and disappearances of goblet cells, which replaced by empty vacuoles with an increased amount of fibrin and congestion in the sub-epithelial layer.

\section{Discussion}

The viral mutation may contribute to different pathological, immunological, replication, and tissue tropism properties [18]. The molecular results suggest that there was one new genotype of IBV not responding to the vaccination process in tested samples, according to the original primer paper [13]. Primer designers named three genotypes to amplify product size of 433 bp were Vaccine A (vaccine strain A Fort Dodge Australia Pty Ltd.), V1/02 (GenBank accession number: FJ235194), and N1/03 (GenBank accession 


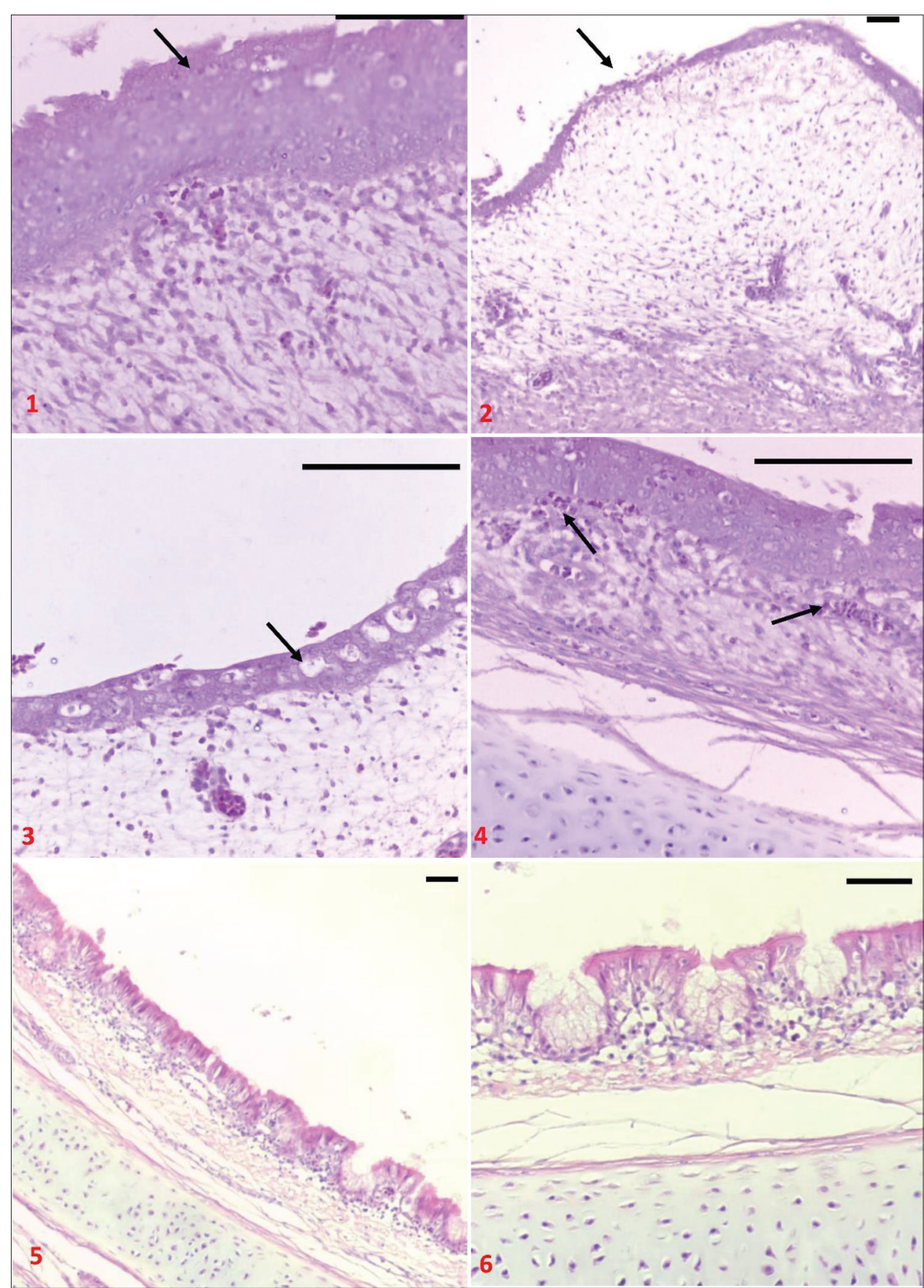

Figure-4: Cross-section in trachea of broiler chicken infected with IBV, 1: Hyperplastic thickening of the epithelial layer, 2: Loss of epithelial layer with cilia over proliferated sub-epithelial layer, 3: Replacement of goblet cells by vacuoles, 4: Subepithelial congestion, 5 and 6: Normal tissue (Hematoxylin and Eosin staining; bar=100 $\mu \mathrm{m}$ ).

number: FJ235190). The results of the current study showed a new fragment (500 bp) not found in Hewson et al. [13], results adding new probable genotype (nucleotides) to the range of UTR primer used in differentiation between IBV strains. The region of interest (UTR) could produce the same amplification product when the strains were similar; otherwise, the UTR sequence could differ from other strains by insertion or deletion nucleotides make a different size of PCR product [19]. Genomic mutations were evidenced in the UTR region of IBV [20]. Researchers revealed that the UTR region contains hypervariable area vary from between IBV strains and may reduce the capacity of the IBV for adsorption [21]. Researchers also recommended not to use the UTR region with S1 gene sequences in phylogenic classification because there is no correlation between IBV strains genome in the UTR region and $\mathrm{S} 1$ gene [20].

These changes agree with other researchers' results, who suggested that the lesions appeared as a result of the apoptotic effect of IBV on cells [22]. The current study results also agreed with other groups of researchers who showed that the IBV causes cellular necrosis and damage after it replicates inside the cells $[23,24]$. Group of Korean researchers agreed with the current study results of renal tubular degeneration 
and acute necrosis of epithelial layer of the trachea, and the Korean researchers concluded that the high inflammatory response induced by cytokines during IBV infection attributed in local renal tissue damage [25]. Researchers who agreed with current study results showed that tissue damage occurred by IBV infection corresponded to the immunological effect of inflammatory mediators from stimulated immune cells, primarily by granzyme and interferon-gamma produced by Natural Killer Cells [26]. Grgić et al. [27] suggest that the IBV is well associated with different stages of trachea hyperplasia. Other researcher showed that some of IBV strains cause tissue damage not only in the respiratory tract but it also causes tissue damage in both renal and tracheal tissues [28].

\section{Conclusion}

The mortality in affected chickens was caused by respiratory distress. The vaccination at 1-day-old did not protect agents' current IBV. Furthermore, we conclude that the virus has an affinity for respiratory and renal tissues. A new probable genotype may emerge.

\section{Authors' Contributions}

All authors participated in the design of the research. MKS: Provided samples and made the prediagnosis to the suspected cases with IIH. STR and IIH: Designed and analyzed the molecular part. NAJ: Histopathological processing was performed and analyzed. All authors drafted, revised and approved the final manuscript.

\section{Acknowledgments}

We thank Salah-Adin Veterinary Teaching Hospital, Tikrit University Central Laboratory and the College of Veterinary Medicine, Tikrit, Iraq, for supporting the research. The authors did not receive any grant from any organization to fund the research.

\section{Competing Interests} interests.

The authors declare that they have no competing

\section{Publisher's Note}

Veterinary World remains neutral with regard to jurisdictional claims in published institutional affiliation.

\section{References}

1. Bande, F., Arshad, S.S., Omar, A.R., Hair-Bejo, M., Mahmuda, A. and Nair, V. (2017) Global distributions and strain diversity of avian infectious bronchitis virus: A review. Anim. Health Res. Rev., 18(1): 70-83.

2. Suryaman, G.K., Soejoedono, R.D., Setiyono, A., Poetri, O.N. and Handharyani, E. (2019) Isolation and characterisation of avian coronavirus from healthy Eclectus parrots (Eclectus roratus) from Indonesia. Vet. World, 12(11): 1797-1805.

3. Miłek, J. and Blicharz-Domańska, K. (2018) Coronaviruses in avian species-review with focus on epidemiology and diagnosis in wild birds. $J$. Vet. Res., 62(3): 249-255.

4. Dimitrov, K.M., Ferreira, H.L., Pantin-Jackwood, M.J.,
Taylor, T.L., Goraichuk, I.V., Crossley, B.M. and Suarez, D.L. (2019) Pathogenicity and transmission of virulent Newcastle disease virus from the 2018-2019 California outbreak and related viruses in young and adult chickens. Virology, 531(1): 203-218.

5. Bande, F., Arshad, S.S., Omar, A.R., Bejo, M.H., Abubakar, M.S. and Abba, Y. (2016) Pathogenesis and diagnostic approaches of avian infectious bronchitis. Adv. Virol., 2016(1): 4621659 .

6. Franzo, G., Legnardi, M., Tucciarone, C.M., Drigo, M., Martini, M. and Cecchinato, M. (2019) Evolution of infectious bronchitis virus in the field after homologous vaccination introduction. Vet. Res., 50(1): 1-9.

7. Jackwood, M.W. (2012) Review of infectious bronchitis virus around the world. Avian Dis. Dig., 7(4): e1-e2.

8. Zhao, Y., Cheng, J.L., Liu, X.Y., Zhao, J., Hu, Y.X. and Zhang, G.Z. (2015) Safety and efficacy of an attenuated Chinese QX-like infectious bronchitis virus strain as a candidate vaccine. Vet. Microbiol., 180(1-2): 49-58.

9. Xu, G., Liu, X.Y., Zhao, Y., Chen, Y., Zhao, J. and Zhang, G.Z. (2016) Characterisation and analysis of an infectious bronchitis virus strain isolated from Southern China in 2013. Virol. J., 13(1): 1-9.

10. de Wit, J.J.S., Cook, J.K.A. and van der Heijden, H.M.J. (2011) Infectious bronchitis virus variants: A review of the history, current situation and control measures. Avian Pathol., 40(3): 223-235.

11. Thor, S.W., Hilt, D.A., Kissinger, J.C., Paterson, A.H. and Jackwood, M.W. (2011) Recombination in avian gamma-coronavirus infectious bronchitis virus. Viruses, 3(9): 1777-1799.

12. Lounas, A., Oumouna-Benachour, K., Medkour, H. and Oumouna, M. (2018) The first evidence of a new genotype of nephropathogenic infectious bronchitis virus circulating in vaccinated and unvaccinated broiler flocks in Algeria. Vet. World, 11(11): 1630-1636.

13. Hewson, K., Noormohammadi, A.H., Devlin, J.M., Mardani, K. and Ignjatovic, J. (2009) Rapid detection and non-subjective characterisation of infectious bronchitis virus isolates using high-resolution melt curve analysis and a mathematical model. Arch. Virol., 154(4): 649-660.

14. Okino, C.H., de Fátima Silva Montassier, M., de Oliveira, A.P. and Montassier, H.J. (2018) Rapid detection and differentiation of avian infectious bronchitis virus: An application of mass genotype by melting temperature analysis in RT-qPCR using SYBR green I. J. Vet. Med. Sci., 80(4): 725-730.

15. Leghari, R.A., Fan, B., Wang, H., Bai, J., Zhang, L., Abro, S.H. and Jiang, P. (2016) Full-length genome sequencing analysis of avian infectious bronchitis virus isolate associated with nephropathogenic infection. Poult. Sci., 95(12): 2921-2929.

16. Masters, P.S. (2006) The molecular biology of coronaviruses. Adv. Virus Res., 65(6): 193-292.

17. Suvarna, K.S., Layton, C. and Bancroft, J.D. (2013) Bancroft's Theory and Practice of Histological Techniques. $7^{\text {th }}$ ed. Churchill Livingstone, China.

18. Zhao, F., Han, Z., Zhang, T., Shao, Y., Kong, X., Ma, H. and Liu, S. (2014) Genomic characteristics and changes of avian infectious bronchitis virus strain CK/CH/LDL/97I after serial passages in chicken embryos. Intervirology, 57(6): 319-330.

19. Liu, X.L., Su, J.L., Zhao, J.X. and Zhang, G.Z. (2009) Complete genome sequence analysis of a predominant infectious bronchitis virus (IBV) strain in China. Virus Genes, 38(1): 56-65.

20. Lachheb, J., Turki, A., Nsiri, J., Fathallah, I., El Behi, I., Larbi, I. and Ghram, A. (2019) Molecular characterisation of a unique variant of avian infectious bronchitis virus in Tunisia. Poult. Sci., 98(10): 4338-4345.

21. Shan, D., Fang, S., Han, Z., Ai, H., Zhao, W., Chen, Y. and Jiang, L. (2020) Since January 2020 Elsevier has Created 
a COVID-19 Resource Centre with Free Information in English and Mandarin on the Novel Coronavirus COVID19. Elsevier, Netherlands.

22. Han, X., Tian, Y., Guan, R., Gao, W., Yang, X., Zhou, L. and Wang, H. (2017) Bronchitis virus infection induces apoptosis during replication in chicken macrophage HD11 cells. Viruses, 9(8): 198.

23. Ignjatovic, J., Ashton, D.F., Reece, R., Scott, P. and Hooper, P. (2002) Pathogenicity of Australian strains of avian infectious bronchitis virus. J. Comp. Pathol., 126(2-3): 115-123.

24. Lee, C.W., Brown, C., Hilt, D.A. and Jackwood, M.W. (2004) Nephropathogenesis of chickens experimentally infected with various strains of infectious bronchitis virus. J. Vet. Med. Sci., 66(7): 835-840.

25. Jang, H., Koo, B.S., Jeon, E.O., Lee, H.R., Lee, S.M. and
Mo, I.P. (2013) Altered pro-inflammatory cytokine mRNA levels in chickens infected with infectious bronchitis virus. Poult. Sci., 92(9): 2290-2298.

26. Okabayashi, T., Kariwa, H., Yokota, S., Iki, S., Indoh, T., Yokosawa, N. and Fujii, N. (2006) Cytokine regulation in SARS coronavirus infection compared to other respiratory virus infections. J. Med. Virol., 78(4): 417-424.

27. Grgić, H., Hunter, D.B., Hunton, P. and Nagy, É. (2008) Pathogenicity of infectious bronchitis virus isolates from Ontario chickens. Can. J. Vet. Res., 72(5): 403-410.

28. Dolz, R., Vergara-Alert, J., Pérez, M., Pujols, J. and Majó, N. (2012) New insights on infectious bronchitis virus pathogenesis: Characterisation of Italy 02 serotype in chicks and adult hens. Vet. Microbiol., 156(3-4): 256-264.

$* * * * * * * *$ 